\title{
George Augustus Sala and the English Middle-Class View of America
}

\section{Peter Blake}

In 1850 George Augustus Sala produced a series of comic panoramas designed to articulate and question middle-class national prejudices during the build-up to the Great Exhibition. There were stereotyped portrayals of revolutionary Frenchmen, cut-throat Italians and cannibalistic New Zealanders, but Sala satirised Americans, and particularly Southerners, more than any other people. For example, his panorama, The House That Paxton Built, shows a Southern slave-owner sitting on two of his slaves. The text reads, 'American Planter's Arm Chair made of ebony - a very free and easy invention supported on slavery.' (see fig. 1) In The Great Exhibition Wot is To Be, an illustration of a black slave jumping in pain as his master whips him appears under the banner 'The Arts and Manufactures of America'. In an accompanying caption - 'This gentleman from his bleeding back may also be taken as a sample of Raw produce' - Sala referenced the 'raw produce' section of the Great Exhibition, seen as the 'least attractive to the general eye' but necessary because its material provided the foundation for all the other exhibits. ${ }^{1}$ Sala's comic panoramas unsettle the idea of the Exhibition as 'a nation on display' - an instrument in the formation of a British national identity - in their stridently anti-colonial and anti-slavery readings of the Great Exhibition's imperialist pretensions. ${ }^{2}$

Sala's subsequent work as a contributor to Dickens's Household Words (1851-57), in which he championed the cause of the poor, identified himself as a Bohemian and questioned the institutions of the establishment, singled him out as one of the most radical of 'Dickens's Young Men' ${ }^{3}$ But when Sala actually visited America for the first time in November 1863, as a reporter for the Daily Telegraph during the Civil War, the letters he sent home were some of the most virulently pro-slavery and

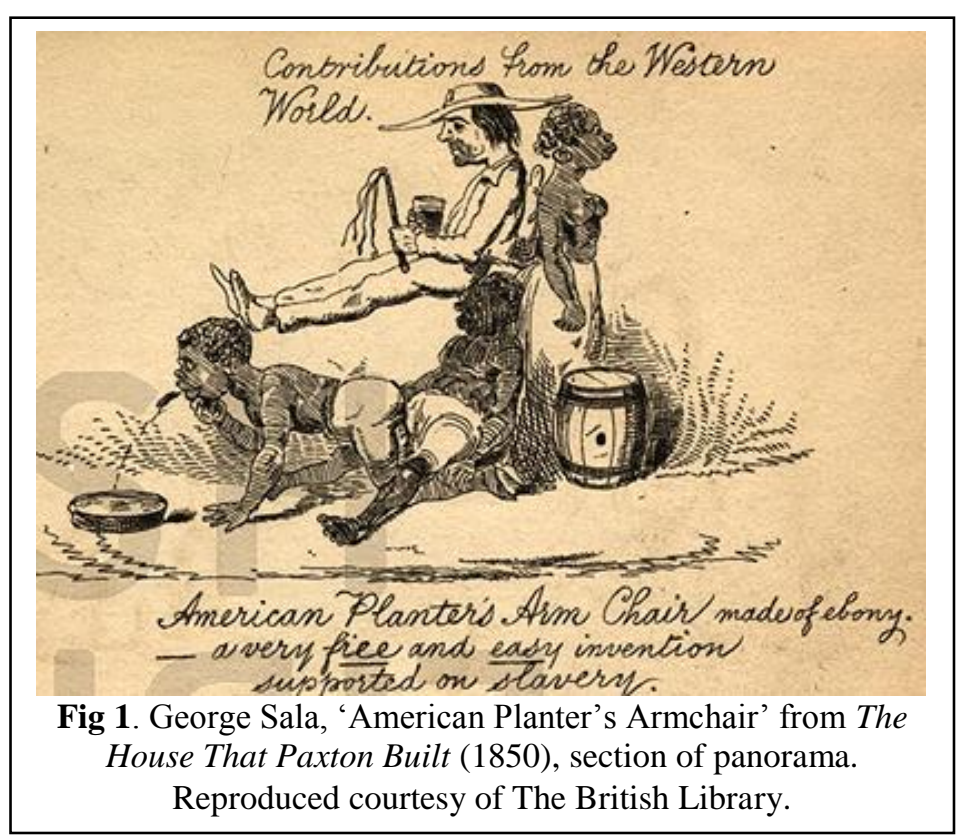


anti-Union missives the English public had yet read. Published in book form in 1865 as My Diary in America in the Midst of War, the letters were so popular with Telegraph readers that Sala's initial six month contract was extended in May 1864 for a further six months. On his later visits to America in 1879 and 1885, he renounced his support for the South as misguided and ill-conceived, but continued to portray African-Americans as unfit to participate in the democratic institutions of the country.

This article considers Sala's shifting views in the context of altering perceptions of race in the ante- and post-bellum eras, drawing on scholarship by Catherine Hall, Robert Young and Tim Barringer, among others, to reassess English middle-class views on race, slavery and America during the second half of the nineteenth century. Although hitherto neglected in previous studies on this subject, Sala is, I contend, an important figure in this debate owing to the influence he commanded over his extensive readership.

In 1850, on the eve of that demonstration of England's economic superiority in the Crystal Palace, Sala knew that satirizing slavery and slave-owners would appeal to an English sense of moral superiority. Slavery had been abolished throughout the British colonies in 1834 and successive British governments had expressed disapproval of what Palmerston called this 'foul and detestable crime'. ${ }^{4}$ But as the 1850 s progressed attitudes towards slavery and race changed. Catherine Hall notes that the assumption of a middleclass attachment to anti-slavery was no longer viable in the 1850 s and 1860 s. The middleclasses had become fatigued by abolition and philanthropy, suspicious of emancipation and its implications for extending the franchise and 'throughout the 1850s a more racist discourse became increasingly legitimate'. ${ }^{5}$ Dickens had spoken out against slavery in his American Notes for General Circulation (1842), but had attacked philanthropists in his 1848 essay on the Niger Expedition in The Examiner and criticized 'telescopic philanthropy' in his portrayal of Mrs. Jellyby in Bleak House (1852). Both Dickens and Thomas Carlyle subscribed to the philosophy that 'the work at home must be completed thoroughly, or there is no hope abroad'. ${ }^{6}$ Applying the contemporary racial science of ethnology to the urban 'other,' Henry Mayhew's letters on 'London Labour and the London Poor' in the Morning Chronicle (1849-64) duly focused on the 'savagery' to be found at home. Archibald Samuel Henning's accompanying illustrations accentuated the blackened faces of the scavengers and chimneysweeps and helped portray the poor as an ethnic group. ${ }^{7}$ 
Tim Barringer notes how Mayhew drew on James Cowles Prichard's Natural History of Man (1843), a key ethnological work, to investigate the way in which physical characteristics could provide information about racial type. ${ }^{8}$ Prichard was from a British tradition of racial science that maintained the superiority of the European and European civilization but felt a moral repugnance towards slavery and believed in the essential humanity of the African. ${ }^{9}$ He was a monogenist, believing that the different races of mankind were all drawn from a single human, biological species. In the conclusion of Natural History of Man, after an exhaustive survey of the multifarious tribes and races to be found across the globe, Prichard highlighted the amenability of 'primitive' men to Christian conversion and claimed that "when we compare this fact with the observations which have been heretofore fully established as to the specific instincts and separate physical endowments of all the distinct tribes of sentient beings in the universe, we are entitled to draw confidently the conclusion that all human races are of one species and one family'. ${ }^{10}$ Nancy Stepan maintains that 'it was this tradition that began to give way in the 1850 s' $(I R S, 44)$. Scientific notions of race led to a new biological and racial determinism culminating in the polygenist theory, the notion that the races of men were as different and separate as humans were to animal species. British scientists like Robert Knox and Charles Hamilton Smith rejected environmental explanations of racial difference and maintained that polygenesis not only explained the different races but also 'proved' the notion of a hierarchy of race, with Europeans at the top and Africans and aboriginal Australians at the bottom.

Thomas Carlyle's essay 'Occasional Discourse on the Negro Question' (1849) argued that Caribbean slaves were an inferior race and could not work hard without the threat of the whip. Carlyle concluded that 'Quashee, if he will not help in bringing out the spices, will get himself made a slave again (which state will be a little less ugly than his present one), and with beneficent whip, since other methods avail not, will be compelled to work'. ${ }^{13}$ Carlyle's analysis, like Mayhew's, 'resonates with the moral discourses of labour' and enforced the differences between racial types. ${ }^{14}$ Hall sees the essay's publication as 'an extremely significant moment in the movement of public opinion away from anti-slavery as the respectable orthodoxy and towards more overt forms of racism' (WMM, 275).

The perceived hypocrisy of abolitionists, who denounced slavery but were willing to profit from the cotton industry while turning a blind eye to the plight of labourers in 
English factories, led to a gradual loss of support for their cause. Harriet Beecher Stowe's Uncle Tom's Cabin (1852) was influential in England and increased the pressure on the slave system, but it also polarized opinion. In the novel the aristocratic and humane slaveowner, Augustine St. Clare, claims that the condition of his slaves is no worse than that of factory operatives in England. Although this was a common defence of slavery in the 1830 s, St. Clare's pronouncement struck a different tone in the 1850s. Elisabeth Gaskell's Mary Barton (1848) and North and South (1854-5), along with Dickens's Hard Times (1854), had exposed the brutality and hardship of the factory regime and the radical English press had taken up this theme in order to denounce the "wage slavery of free labour' in England. An article from the radical working class paper Reynolds's Newspaper from 10 April 1853 criticised abolitionist sentiment and stated that 'workers in factories are as much slaves to the money-power as the negroes in the United States are to the lash'. ${ }^{15}$ In December 1857 the organ of the middle-class establishment, The Times, published a series of leaders reassessing the wisdom of slave emancipation. Echoing Carlyle's analysis, the leaders argued that the inherent laziness of the Negro race had produced the economic difficulties to be found in the West Indies. ${ }^{16}$ The Times's strong pro-Southern stand was due in part to the West Indian origins of its manager, Mowbray Morris, but the African-American ex-slave and abolitionist Frederick Douglass commented during his second visit to England in 1859 on the growing disillusionment with the success of West Indian emancipation along with a troubling rise in racism. As far as Douglass, author of Narrative of the Life of Frederick Douglass, an American Slave (1845) was concerned, the two were related and the product of a growing American influence in Britain. Carlyle argued that emancipation had been an abject failure because 'it freed a people incapable of appreciating the boon of freedom and failed to put in place a new order that regulated labor'. ${ }^{17}$ R.J.M. Blackett notes how 'Southern supporters saw little to dispute in Carlyle's analysis and warned against the danger of repeating the failures of the West Indian experiment'. ${ }^{17}$ We can observe, then, how during the shifting cultural and scientific racial climate of the 1850s significant portions of English middleclass opinion began to gradually move away from a position of abolitionism to one whereby not only the wisdom of emancipating American slaves was challenged, but so too was their essential humanity.

The 1850s were also the dawn of the age of African exploration. Sir Richard Burton, the polymath and explorer (and friend of Sala), believed that his numerous 
expeditions to Africa had given him privileged access to the innate abilities of Africans. Dane Kennedy notes Burton's belief that 'slavery was the great civilizing agent of primitive races'. Burton argued that the African could not improve in his own country, and that 'the removal of the Negro from Africa is like sending a boy to school; it his only chance of improvement'. ${ }^{18}$ The idea of white superiority had entered mainstream discourse with the scientific racism of James Hunt, a disciple of Knox, and the work of the Anthropological Society of London, formed in 1863. Hunt was one of the most significant proponents of polygenesis and stated that 'no man who thoroughly investigates with an unbiased mind, can doubt that the Negro belongs to a distinct type [...] there is in the Negro that assemblage of evidence which would, ipso facto, induce the unbiased observer to make the European and the negro distinct types of man' (IRS, 3). Although Charles Darwin was brought up as an abolitionist and monogenist, the racial manipulation of his theories of natural selection described in the Origin of Species (1859) meant that 'far from dislodging old racial ideas, evolution strengthened them, and provided them with a new scientific vocabulary of struggle and survival' (IRS, 49). In The Descent of Man and Selection in Relation to Sex (1871), Darwin tried to establish the continuity between animals and man and he used the example of 'savages' and lower races to prove his point. Stepan suggests that 'later, scientists would find it only too easy to interpret Darwin as meaning that the races of man now formed an evolutionary scale' (IRS, 55). Even a celebrated abolitionist and adherent of Darwin's theories like T.H. Huxley had, by the end of the American Civil War, worked through Darwin's theory of evolution and come to the conclusion that the 'innate inferiority' of African races 'held them to a low place in the scale of civilization' (IRS, 79).

\section{I}

Sala had observed for himself the workings of white slavery in 1856 while traveling through Russia and reporting for Household Words. His visit came only five years before the emancipation of the serfs and at a time when serfdom was 'widely recognised as an institution on its last legs'. ${ }^{18}$ Sala portrays white slavery in Russia as morally wrong, anachronistic and indefensible. Using as an example Princess Shiliapoff, whose twenty-five hundred crown serfs were beaten or sent to Siberia for the slightest misdemeanour, Sala openly baited Harriet Beecher Stowe for highlighting the injustices of black slavery while turning a blind eye to the subjection of people with her own skin 
colour: 'And these good people are WHITE, Mrs. Harriet Beecher Stowe, White, ma'am!' ${ }^{19}$ Sala implied that black slaves in America had been held up as victims requiring the attention of English abolitionists and philanthropists, while closer to home, in Russia and, in all but name, in England, there were white slaves more deserving of sympathy and philanthropic attention than their trans-Atlantic counterparts. Comparing the treatment of aristocratic serfs to crown serfs, Sala likened the former to slaves in the American South and the latter to the poor in London's parishes:

As regards their rigid necessity - the bare elements of food, covering, and shelter, - the nobility's serfs have decidedly the same advantage over the twenty millions or so of crown slaves as Mr. Legree's negroes have over the free-born British paupers of Buckinghamshire or Gloucestershire, or - out with it - St. James's, Westminster, and St. George's, Hanover Square. (JDN, 155)

In line with a growing public sentiment back in England, Sala suggested that black slaves in the American South actually had more advantages than the 'free' labour of the English working class. Sala went on to paint a flattering and idealistic portrayal of the typical white Russian male slave, who 'is kind; he is grateful; he is affectionate; not quarrelsome when drunk; untiringly industrious [...] ordinarily frugal' (JDN, 213). Three years earlier, in 1853, Charles Dickens had already begun to incorporate a more racial discourse into the contents of Household Words. Dickens's own article, 'The Noble Savage', stated trenchantly that 'I call a savage something highly desirable to be civilized off the face of the earth'. ${ }^{20}$ Dickens's experiences of American vulgarity in 1842 brought him to this conclusion. Jerome Meckier suggests that 'from Americans Dickens learned that innocence (that is, not knowing how one appears in the eyes of one's peers) can be a particularly objectionable form of vulgarity that tells heavily against Rousseau's respect for simpler kinds of social organization [...] The most natural thing for man to do, Dickens discovered, was to become more and more civilized as quickly as possible'. ${ }^{21}$

Of course there were still many anti-slavery voices to be heard. Lord Denman, writing a riposte to Dickens's article in the Chronicle, suggested that it 'appears to have been written for the taste of slave traders only'. ${ }^{22}$ Dickens himself fostered the publication of several essays maintaining an anti-slavery stance in Household Words. Harriet Martineau's article 'Freedom or Slavery?' was a reaction against the Fugitive Slave Act passed by Congress on 18 September 1850, which declared that all runaway slaves must be returned to their masters, even from non slave-holding states. ${ }^{23}$ Martineau invoked the 
spirit of resistance shown by Bostonians prior to the Revolutionary War and hoped the same spirit would be shown in the fight against slavery. Eliza Lynn Linton's 'Slaves and Their Masters', written with Dickens's sub-editor W.H. Wills, came to the conclusion that 'slave-holding is degrading to both masters and slave, despite the sophistries of the south to show its mercy and its value'. ${ }^{24}$ An article written by William Blanchard Jerrold, also anti-slavery in sentiment, highlighted the significance of cotton to the British economy and suggested that over-reliance on the slave states for this raw material would lead to potential disaster. ${ }^{25}$ Jerrold presciently described how both the lowly weaver and the Manchester cotton lord 'tremble at the least rumour of war with the Yankees' for fear of the economic consequences to the cotton industry in Britain and advocated alternatives such as West Indian and West African cotton cultivation to offset this Southern American monopoly.

But despite these anti-slavery voices it was sentiments like those laid down in 'The Noble Savage' and 'Occasional Discourse on the Negro Question', written by eminent men of letters like Dickens and Carlyle, allied with the economic reliance on the cotton trade, that paved the way for a shift in middle-class allegiance from outright abolitionism to a more pro-Southern and pro-slavery position during the late 1850 s and early 1860 s. While Dickens would maintain his emancipationist and anti-slavery principles he would increasingly discredit the notion that African-Americans could become involved in the democratic process of self-government.

The Daily Telegraph was, like its later 'Special Commissioner', representative of this changing attitude towards race and slavery. Although politically neutral at its founding in 1855 , a leader from 24 November 1856 admitted to having espoused the cause of John C. Fremont in that year's American presidential election. Fremont was the first presidential candidate of a major party to run on a platform in opposition to slavery. The leader stated that 'we knew that every inch of ground advanced by Fremont, in his struggle, inflicted a blow upon the abominable slave system'. ${ }^{26}$ But with increasing influence of scientific and cultural racial discourses prior to the American Civil War the Telegraph had, along with The Times, given its full support to the Confederacy and had become one of the most pro-Southern of British newspapers. Given Sala's criticism of, and subsequent mauling by the American press, there is some irony in the fact that the Telegraph modelled itself after New York journalism; the news was sensationalised and the style colloquial. Prominence was given to divorce proceedings and news from the 
bankruptcy court. This willingness to mimic aspects of American culture was an early indication of the growing 'special relationship' between Britain and America, and Sala's subsequent negative comments on the country in this newspaper highlight some of the contradictions he was working within.

In 1857 Sala embarked on what would become a thirty-year association with the Telegraph, after falling out with Dickens over financial matters and Sala's own increasingly erratic and bohemian lifestyle. Sala's witty leaders for the Telegraph and his blend of sensational journalism, mixing 'true crime', news stories, and personal accounts of royalty and celebrity, had by 1861 helped the Telegraph outstrip the circulation of The Times and made Sala one of its 'young lions'. ${ }^{27}$ Although both Sala and the Telegraph were denounced by highbrow critics like Matthew Arnold and the Saturday Review for being the epitome of Philistinism, the paper had nevertheless impressed its growing legion of middle-class readers. During the war in America, Sala performed the role of 'Special Commissioner' for the Telegraph, reporting back to England on the general condition of the country and its people, whilst Edward Dicey reported in detail on the conflict from the American battlefields as Special Correspondent for the same paper. When he first arrived in America, Sala was taken to Washington to see the opening of the $38^{\text {th }}$ Congress. Despite assuming the slightly condescending tone of a father writing to a long-lost son, Sala was reasonably complimentary: 'Everything which I beheld appeared to me thoroughly modest, simple and noble - the free citizens of a great commonwealth setting about the task of governing themselves, and doing it sensibly and well. ${ }^{28}$ As we shall see, this paternalistic stance would soon be applied to the African-American population. Sala became concerned that compared to the exciting and sensational reports from the frontline by his colleagues his more sedate role would obstruct 'the foreground of the picture with details which will appear petty and frivolous when compared with the colossal sweep of the heroic vista'. ${ }^{29}$ Due to his growing impatience at being denied access to the South for security reasons, Sala's predictable attacks on everyday Northern life certainly take on a 'petty and frivolous' nature. In fact, many of his negative comments could have been taken from any one of the accounts of his illustrious British predecessors in America: Dickens, Frances Trollope, Harriet Martineau or Captain Marryat. The observations of these earlier writers on America are a constant reference point in Sala's letters. Although the political analyses of these commentators differed, their pronouncements on the cultural inadequacies of American life were strikingly uniform.

Peter Blake, George Augustus Sala and the English Middle-Class View of America

19: Interdisciplinary Studies in the Long Nineteenth Century, 9 (2009) www.19.bbk.ac.uk 
Meckier suggests that on his first visit to America in 1842, 'writing about America entailed [Dickens] writing about all of the best-known previous guidebooks. ${ }^{30}$ Sala imitates Dickens's technique in this respect and provides his Telegraph readers with a familiar framework of observations: details of a hopelessly inefficient railroad system; accounts of incivility on the part of officials; the extreme taciturnity of the working class; the overbearing and coquettish women; the ubiquity of spittoons; the low standards of the press; the insufferable children who are spoilt and receive no punishment; the filth and squalor of the streets of New York. These criticisms were the staple material of earlier British commentaries on America and imparted a sense of superiority and smugness as the New World was once again put in its place. Sala even used a pig as a symbol of how New York street life had deteriorated since Dickens's visit: 'He is the same pig, or that pig's great grand-son, that Mr. Dickens saw when he was here; only a pig that has fallen on evil days - a pig that has been exiled from decent society - a pig that has gone to the dogs.' (MDA, 1: 413) But in the same way that Dickens depicted slavery as 'a wellspring of atrocities in order both to outclass the outraged Harriet Martineau and to remedy Fanny Trollope's sketchy treatment of a national disgrace', Sala also chose to 'outclass' Dickens, Martineau and Trollope. ${ }^{31} \mathrm{He}$ did not do this in the same manner as Dickens, who exaggerated his predecessor's views and made them appear pedestrian, but rather distanced himself from such earlier commentators by breaking with their views on race and slavery altogether. ${ }^{32}$ Sala was conscious that this American assignment was an opportunity for him to shed the shackles of anonymity imposed by editorial practices. He was endeavouring to forge his own journalistic identity by formulating a radically different impression of America from that of his predecessors,

Although Sala was refused access to the South and never actually witnessed the workings of the 'peculiar institution' of slavery, he was unable to contain his excitement when, via a telescope and a steep climb up Poney Mountain in Culpepper, Virginia, he was given the opportunity to witness General Robert E. Lee's Confederate Army. It was Sala's first and only view of the South on this visit and his impressions were shattered when instead of the rich, fertile land he expected, he saw a 'howling wilderness', with 'no trees, hedgerows, or gardens visible. All was incult and horrid - without form and void'. (MDA, 1: 340) Although in Dickens's account of America from 1842 the 'ruin of the land is a metonymy for the moral ruin created by slavery', for Sala it became an example of the ruin that necessarily occurred when the slave system was removed. ${ }^{33}$ Sala thus inverted 
the free labour critique and stated that 'the curse [slavery] has departed, and so have the blessings. The slaves are gone, and so is the land, and the fatness thereof' (MDA, 1: 340). Sala left his readers in no doubt who was to blame for all of this desolation: 'The Federals have simply acted the part of a swarm of locusts, and devoured the land. They have rioted on the fatness thereof, and they have left nothing for those who are to come afterwards.' (MDA, 1: 266-7) The disappointment he felt on finally witnessing his beloved South led him to begin a full-frontal assault not only on the North, but also on the black population of North and South.

Sala insisted that only the South held the true 'Anglo-Saxon stock' and that the North were 'aliens who had sold themselves for certain sums of money'. He stressed the 'despotism' of Northern politicians, and blamed the Northerners for 'unleashing a tyrannical and fratricidal war in the name of a specious piety and humanitarianism'. ${ }^{34} \mathrm{He}$ even refused to meet his literary heroes, Oliver Wendell Holmes and Ralph Waldo Emerson, because of what he considered their 'complacent acquiescence in a vulgar 'scallwagg' despotism' (MDA, 1: 413). Warning his readers of the barbarous and uncultivated qualities of white Northerners, Sala used the type of language he would later reserve for the slave population: 'you must beware of the Yankee,' he wrote, 'in an underground bar, "tight" and with a pistol or knife in his pocket, he is about the savagest creature to be found out of the country of the gorillas.' (MDA, 2: 316.) Sala denounced the treatment of free blacks in the North and claimed that 'of all the miserable and woebegone objects I ever beheld out of a Russian gaol or an Italian lazar-house, the free negroes I have seen in New York are the wretchedest and most forlorn' (MDA, 2: 42). Echoing Carlyle's gloom-laden fears on emancipation, Sala informed his readers that if we 'turn them loose in the blessed land of freedom' then we will 'see how long it will be before they hopelessly deteriorate' (MDA, 2: 43). He ended his diatribe with a rejection of the North's reasons for the cause of the war and the effect it would have on the black population: 'You told me, you told us, you told England and Europe that yours was a righteous war and a holy crusade to emancipate the Black Man [...] instead you have been emancipating him into the grave by the thousand and the tens of thousands.' (MDA, 2: 48)

Sala totally disregarded claims of the maltreatment of slaves and in his strongest statement on the slave system, published in the Daily Telegraph on 2 January 1864 just after Lincoln's Emancipation Proclamation, he maintained: 
That I believe slavery to be an evil, and to a certain extent a curse: but that it is not a worse evil nor a worse curse than Prostitution, than Drunkenness, than Pauperism, than the tyranny of capital over labour, or than the greed for wealth and dominion [...] I believe that he [the black man] is and has been ten thousand times better off as a bond-servant in the Southern States of America than as a free negro in the North [...] I believe that he is naturally inferior to the white man in mental organisation [...] willing and obedient only when he fears the eye or the hand of his master [...] always as lecherous as a monkey and often as savage as a Gorilla [...] I believe that he must always have a 'boss' or a master or guide of some sort over him [...] and I believe that in default of this master, guide, or 'boss,' he will go to the Devil [...] as he has been going in his own country, Africa, for I don't know how many thousand years. (MDA, 2: 37-40)

The influence of contemporary racial thought on Sala is not difficult to detect. He iterates Burton's paternalism when regarding slavery as the 'great civilizing agent of primitive races' and Carlyle's insistence on the inherent laziness of Africans. The notion of idleness had become a major current in racial discourse at this time. Catherine Hall argues that one of the ways in which white middle-class males in this period were able to 'silence the disruptive relations of ethnicity' and to assert for themselves a secure and stable English identity was to 'define themselves in relation to others' (WMM, 206). Carlyle's belief in the morality of a Puritan work ethic would be reinforced if it could be shown that Africans could not and would not undertake hard labour. In a chapter of his autobiography entitled 'Lotus Eating', Sala pointed out that during the 1850s 'a lazier and more dissolute young loafer' than he did not exist. ${ }^{35}$ By defending Carlyle's views on the idleness of Africans Sala was able to disassociate himself from his bohemian days and refashion himself as a tireless, industrious, and hence more respectable, journalist. Sala also repeated the polygenist argument of Knox and Hunt on the hierarchy of race when he alluded to the 'natural inferiority' of African slaves compared to their white counterparts. By comparing Africans to monkeys and gorillas, Sala was engaged in racially manipulating Darwin's ideas of evolution.

It was not only Sala's views on the subjects of race and slavery that had changed so radically since his satires on slave-owners in 1850: it seems that his readership had also altered their opinions on the subject. In the letters section of the Telegraph there are no indications that readers found Sala's views offensive or biased. In fact the only letter printed in the Telegraph that referred to Sala's journey was in the 8 January 1864 edition and contained a rather innocuous protest at his unfavourable comparison of the morose and surly janitors at the House of Commons with the civil doorkeeper of the House of 
Congress. Nearly eighteen months before the spectacular 'war' over the Governor Eyre Affair was played out in the British press, Sala was persuading his readers of the inferiority of the 'Negro race' in precisely the same terms that Carlyle and other members of the Eyre Defence Committee would use.

Sala claimed in an introductory chapter of My Diary in America in the Midst of War that his support for the slave system resulted from his family history. Like Mowbray Morris of the Times, Sala's grandfather had been a West Indian slave-owner and the advent of abolition there had meant that, despite compensation, his family had experienced financial hardship. P.D. Edwards speculates that Sala's forthright opinions are thus best explained as 'a gesture of piety to his mother's memory' ${ }^{36}$ It seems more likely that Sala had been swept up by the climate of increasingly racialized thinking and that he was once again articulating his readers' prejudices and providing them with the sensational views of race and slavery that they desired. Sala's defence of his views was also an important element in his romanticised image of the Special Correspondent. He asked his readers, 'should a strong man be ashamed to avow that his Book is Himself, and that in whatsoever he writes that treats of individual thought or individual opinion, he must be, to a great extent, his own hero?'(MDA, 1: 14) But as support for the South escalated in Britain, it became clear that if these were Sala's personal opinions then they were shared by his Telegraph readership. At the height of their popularity, there were over 250,000 readers of Sala's letters. If Sala's views were representative it suggests an alarming retreat from the emancipationist zeal of the $1830 \mathrm{~s}$, and the anti-slavery sentiments of Dickens and Harriet Beecher Stowe in the 1840s and 1850s. Did Sala change attitudes or merely reflect existing prejudices that were deepened by the Civil War? Although support for the Confederacy was strong in Britain, scholars have tended to put this down to conservatives' dislike of American democracy and liberals' enthusiasm for national liberation causes rather than to a resurgence of support for slavery. ${ }^{37}$ But how else do we account for the lack of reaction to Sala's pro-slavery outbursts from his Telegraph readers? It seems from the lack of critical response to Sala's opinions that any criticism of England in the Telegraph, no matter how puerile, was subject to censure, while the United States could be damned to impunity in a climate of collective hysteria, exaggeration and sensationalism.

Of course Sala's was not the only pro-Southern British account published during the war. Samuel Phillips Day, a journalist with the London Morning Herald, reported on 
the events of the South in 1861. His book Down South, or an Englishman's Experience at the Seat of the American War (1862) was an attempt to persuade his fellow countrymen against joining in the war. His sympathies were fully with the South and he believed that the Northern 'efforts to subjugate the South were futile and criminal'. ${ }^{38}$ In 1863, Arthur Fremantle, a Lieutenant in the Coldstream Guards, travelled behind Confederate lines. Sympathetic to the military life he witnessed, like Day he refused to accede that the South could ever be subdued. The record of his travels was published as Three Months in the Southern States (1863). T.D. Ozanne was an English clergyman who had resided in the South for over twenty years. His The South As It Is (1863) was an attempt to 'justify the Southern way of life and point out the dangers of hasty emancipation.' (BVA, 246) In fact there were so many partisan accounts of the South that Anthony Trollope's book North America (1862), detailing his nine months in America from August 1861 to May 1862, was significant because of the author's Northern bias. As Catherine Hall suggests, 'the existence of powerful pro-Southern feeling during the Civil War was [...] clearly an indicator of the shifts which had occurred in some sectors of public opinion on the subject of slavery and the rights of black peoples.' (WMM, 276) But despite the preponderance of Southern favouritism, Sala's prejudice against the North seems to have singled him out for attack by the American press.

On his return from Virginia Sala witnessed the lively Fourth of July celebrations in New York. Dismayed at the incessant noise and dangerous firework explosions, he likened Americans' partiality for noisy pyrotechnics to that of the Chinese and felt that the two nations had in common a 'lingering presence of barbarism in the land, and [an] inherent childishness of the people.' (MDA, 1: 349) Although British tourists to America, both before and after the Civil War, had found youthfulness a suitable trope for the country, nobody had extended this metaphor quite so far as Sala. W.H. Russell typically represented America as 'a lusty youth, promising a manhood of irresistible vigour and strength in time to come if the body politic fulfils its early hope' $(B V A, 72)$. But Sala equated youthful vigour and exuberance to petty childishness and in another forthright attack he used this as a political metaphor: 'they play at law, religion, government, and science. The children are the most precocious in the world; but the grown men and women, with all their undeniable smartness and cleverness, are in many respects the biggest babies I ever saw or knew.' (MDA, 1: 349) These comments can be read as a natural extension of Burton and Carlyle's paternalism regarding slavery, emphasizing the 
need for a hierarchy in which social or intellectual 'betters' determine the well-being of their 'inferiors'. Sala extends this to the old democracy of England and the young transatlantic upstart.

When Sala's views appeared in the American press they provoked 'a howl of rage which did not die down until long after his departure'. ${ }^{39}$ The newspapers variously dubbed Sala a 'bloated miscreant', a 'fat cockney', a 'venal hack'. a 'Secesh spy' and 'the enemy of the country and deserving of a lynching'. ${ }^{40}$ Even Sala's old friend from his bohemian Parisian days, Horace Greeley, now editor of the New York Tribune, would not relent. In November 1864 Greeley printed an acerbic attack in the Tribune:

The number of the Atlantic for January begins the $15^{\text {th }}$ volume, for which a liberal programme is presented in the announcement of the publishers. One black streak, however, is given to the rainbow, by inserting the name of the infamous English hireling Sala, among the respectable men who are engaged as contributors. The presence of that indecent and mendacious buffoon, who is known chiefly in this country as the foul-mouthed correspondent of some English newspaper, will be as disgusting in the pages of the Atlantic as was the company of Satan among the sons of the Lord. ${ }^{41}$

So much for camaraderie and friendship among fellow journalists. In fact, Sala complained that the editors of the New York papers were quite happy to invite him out to dinner but would then castigate him in print the following day. What we can sense from these exchanges is that, unsurprisingly, both American and English journalists were giving their readers precisely what they wanted. In the Telegraph's case this meant sensationalism tied in with virulent anti-Northern prejudice, while the American newspapers knew that denigrating an offensive Old World traveller would always be a safe way of increasing circulation figures. There was added irony because Sala's style of journalism was so indebted to the American newspapers. Sala was the English representative of the new mass media that the American press had pioneered, and that had so disappointed Dickens twenty years earlier. Perhaps this explains why the American Fourth Estate, believing that Sala was a representative of the Old World who could actually be considered as 'one of their own', was even more disappointed when he adopted a negative stance towards the North. ${ }^{42}$

The British press was less severe towards Sala: even the staunchly pro-Union reviewers praised the quality of his writing while unsurprisingly disagreeing with his views on slavery. Reviewing Sala's book for the Methodist organ, the London Quarterly Review, the anti-slavery campaigner and ex-Indian missionary William Arthur felt that 
'[Sala] soon threw off the vain semblance [of partiality], and became the open and extreme partisan of the South; and now, with marvellous simplicity, he appears both to wonder and to grieve at the supposition that the North does not like him. Our only wonder is that the people whom he systematically libelled did not at once ship him off from its shores'. Arthur points out that W.H. Russell, to whom Sala dedicates his American book, had just inserted in his most recent publication, Canada, the caveat that 'slavery is to me truly detestable; the more I saw of it, the less I liked it'. But Arthur also admits that 'in the two handsome volumes before us there is much to amuse; and we do not doubt but that they will have a wide circle of readers. There is, in fact, scarcely a dull page in them; and of how few books can this be said! ${ }^{43}$ The anonymous reviewer for the Illustrated London News, to which Sala was himself a contributor, wrote that 'one is pained at Mr. Sala's views on the negro question; but, on the whole, one is inclined to look upon his picture as a faithful representation of matters as they appeared to a writer who was far from a Northern sympathiser; who was on the lookout for literary capital, and who was expected to make of his capital the most that he possibly could'. ${ }^{44}$ We can observe from these exchanges that Sala's views on the subjects of race and slavery were not completely representative. His opponents, however, were prepared to forgive his opinions. They acknowledged the political and cultural contexts that Sala operated in and appreciated the sensationalisation of his reports. What they perhaps failed to consider was the extent to which Sala's letters influenced his middle-class readership. This influence would be played out against the backdrop of a Jamaican uprising.

On his return home, Sala was met with the first rumblings of discontent over the Governor Eyre Affair. On 11 October 1865 a crowd of black settlers protested before the court house of Morant Bay in Jamaica over the harsh sentences imposed by local magistrates on black squatters. When the local militia fired into the crowd, killing seven protestors, the mob set fire to the court house and murdered members of the militia. The Governor of Kingston, Edward John Eyre, ordered troops to Morant Bay and executed 439 of the native black population, while 600 were flogged and 1,000 houses burned to the ground. George William Gordon, a member of the Jamaican House of Assembly and illegitimate son of a white planter by a slave-woman had been summarily court-martialed and hanged. As Douglas A. Lorimer states, 'following fast on the heels of the American Civil War, the Governor Eyre controversy prolonged the mid-Victorian debate about the Negro,' and battle lines began to be drawn in England. ${ }^{45}$ Adam Roberts notes that Alfred 
Tennyson's response to the setting up of the Jamaica Committee by Thomas Hughes, Charles Buxton and John Stuart Mill was not untypical: 'We are too tender to savages; we are more tender to a black man than to ourselves. Niggers are tigers, niggers are tigers. ${ }^{46}$

The Jamaica Committee wanted the government to prosecute Eyre for his overzealous handling of events in Morant Bay and this in turn led to the organization of the Eyre Defence Committee, with Carlyle, Tennyson and Dickens as its most prominent members. Sympathy for Eyre, notes Hall, was 'linked into the growing fears amongst the middle-class of working-class activity around the issue of reform'. (WMM, 277) In a leader in the Daily Telegraph from 14 November 1865, possibly written by Sala, the black population is portrayed as a mass of child-like savages threatening the lives and honour of English men and women. ${ }^{47}$ The ultimate failure of the Jamaica Committee - Eyre was not reinstated, but he did not stand trial for any of the charges brought against him and received a pension in 1873 - ushered in what Hall describes as 'a new hegemony'. Whereas in 1849 Carlyle's racial proclamations had been of an isolated nature, in 1866 he was fully backed by this growing hegemony, a conservative movement that would go on to construct 'a new popular imperialism in the decades to follow' (WMM, 286). J.S. Mill was convinced that the Jamaica Committee ultimately failed because of a lack of middleclass support and Sala's Telegraph readership would certainly have been guilty of this charge. In the aftermath of the Eyre Affair Carlyle's influence could be judged as 'elevating and sustaining the tone of the nation in a conservative, ethnocentric and racist

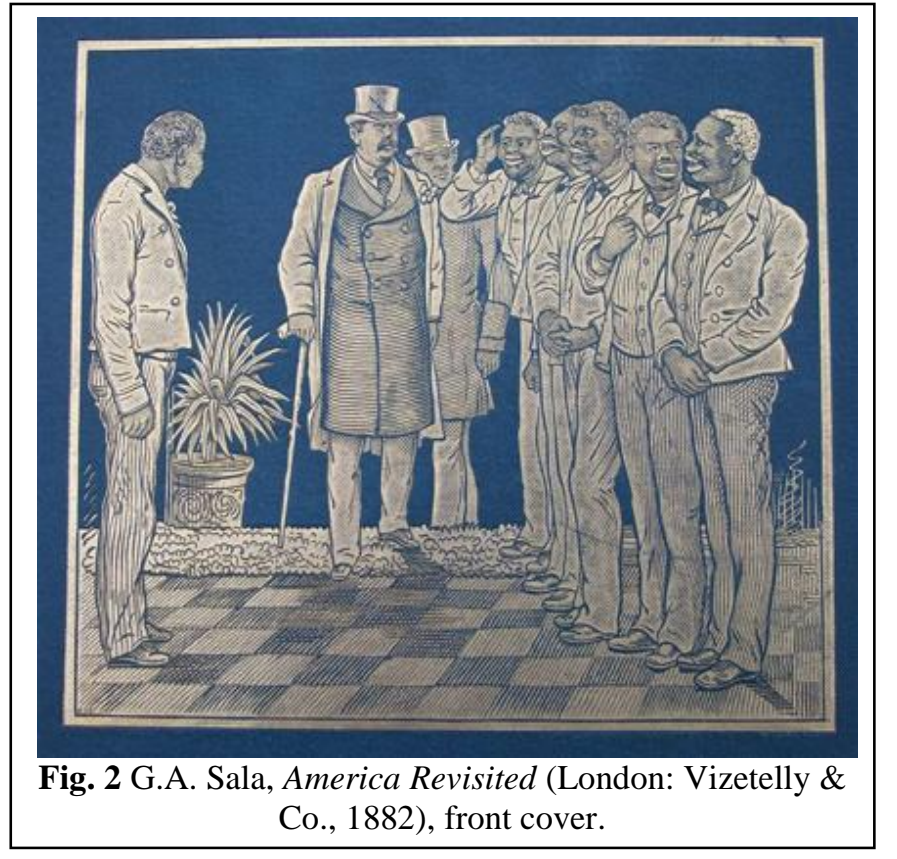

conception of Englishness' (WMM, 288-89). As we shall see, Sala would increasingly adopt this tone on his next American visits.

Unsurprisingly, given the North's victory and his reception by the press, Sala remarked in an article for Belgravia magazine in 1868 that 'I dare not return to America', but in 1879 he was once again commissioned by the Telegraph to report on American affairs. $^{48}$ Unlike W.H. Russell, 
whose return twenty years after the Civil War had seen him 'grow more opinionated than he had ever been', Sala had changed his stance so appreciably that he was able to beg forgiveness for taking what he now considered the wrong side, writing that he had been 'very prejudiced, very conceited, and very ignorant' for doing so $(B V A, 251)$. The resulting letters were published in 1882 as America Revisited (see fig. 2).

As indicated by the cover, with its caricatured black 'sambo' figures who appear unable to resist fidgeting and inanely grinning while waiting to be introduced to Sala, portrayed as the archetypal middle-class English gentleman, there were no signs that Sala's racial views had similarly altered. This time his travels across America encompassed the Deep South, the Mid-West and the Far-West and while observing segregation on a Pullman train from Baltimore to Washington, Sala naively suggests that 'it did not appear to me that they were in any manner coerced into thus segregating themselves from their white brothers and sisters. They seemed to keep themselves apart as much from choice as from custom. ${ }^{49}$ In Washington he remarked on how 'the black man [...] seemed to be doing remarkably well', adding 'I found all the coloured people with whom I came in contact [...] invariably civil and obliging' $(A R, 1: 201)$. Sala's affections still obviously rested with the South despite his apology for backing the Confederacy during the war. On arriving in Richmond he stated that 'it is a Genial City; that is enough for me; and in the whole course of my travels I have not met with a more courteous, a kindlier, or a more simple-hearted people than I have met with here' (AR, 1: 251). In Virginia he complained at the black 'cross-road loungers' he encountered and gave the impression that under the slave-system these types of loafers did not exist. Although he detailed their ragged clothing and hungry and emaciated look, he stated that 'the negroes are probably much better off than they look, from a sumptuary point of view, and in fact I fail to see that they have very much to complain of' $(A R, 1: 241)$.

Visiting the Deep South at the tail end of the Reconstruction Era, Sala witnessed free slaves in positions of authority in the New Orleans House of Representatives. While those of a fairer skin, the 'mulattos', were seen as possessing reasonable intelligence, the 'true-blooded negro' was, Sala believed, completely out of his depth. Sala seems to suggest that a return to slavery, where he believed miscegenation had proliferated, would be desirable and lead to a dilution of the unwanted 'true-blooded negro', but he notes that in the current climate miscegenation 'is simply a social impossibility' due to the prevalence of lynching $(A R, 1: 255)$. The term 'miscegenation', describing inter-racial sex 
was, Robert Young suggests, 'at the heart of Victorian race theory' and its first recorded use occurs in $1864 .^{50}$ Polygenists claimed that descendants of these unions quickly displayed signs of degeneration but the proliferation of mixed-race offspring in the American South also hinted at the erotic "power relation between slave-owner and slave'. ${ }^{51}$ Sala's desire for more inter-racial mixing demonstrates some of the muddled thinking of nineteenth-century notions of what Young terms 'hybridity'. While his references to the 'picturesque and fantastic negresses' $(A R, 2: 93)$ at the Mardi Gras hint at the disgust and desire underpinning colonial relations, Sala's argument that slavery actually promoted better and closer relations between blacks and whites was a common Southern justification of slavery before the war.

Sala even went as far as to give a back-handed compliment to the 'coloured members' of the New Orleans legislature: despite their lack of imagination and independent thought 'as regards Parliamentary procedure, the coloured members are very often not only on a par with, but superior to, their white colleagues' ( $A R, 2: 54)$. He summarised his position on these law-makers: 'Our dark brother as a legislator must [...] be considered as in an infantile condition'. ( $A R, 2: 54$, see fig. 3)

Sala's attitude towards the free slave population in the South as a whole is encapsulated in his conclusion that 'the negro is, from many different aspects, a bad job; but the Southerners are trying hard to make the best of him' (AR, 1: 235). Dickens held similar views. On his second visit to America in 1868 he commented that 'the melancholy absurdity of giving these people votes, at any rate at present, would glare out of every roll

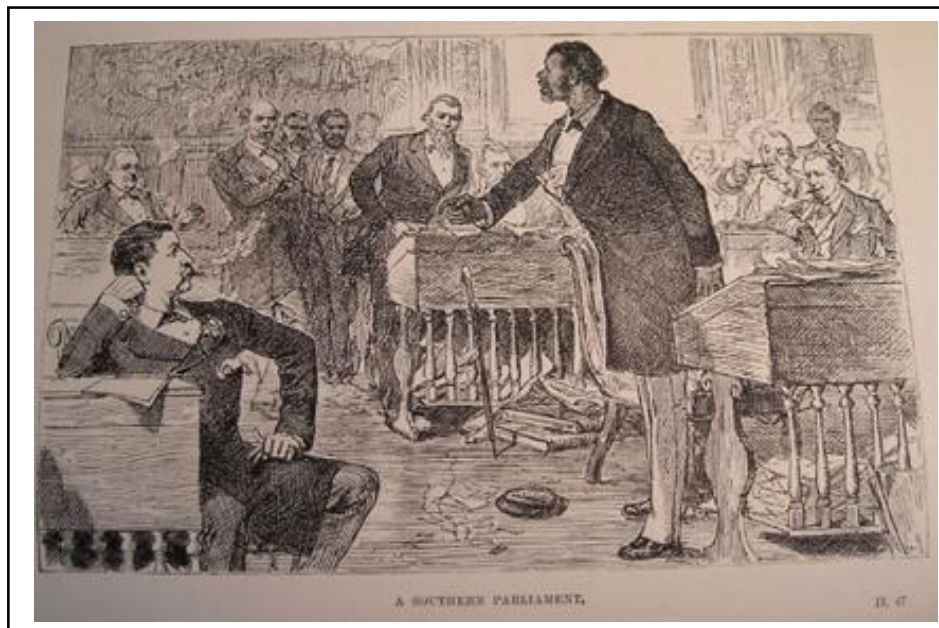

Fig. 3 G.A. Sala, America Revisited (London: Vizetelly \& Co., 1882), illustration p.46. of their eyes, chuckle in their mouths, and bump in their heads' (see fig. 4). ${ }^{52}$ The shift in cultural and scientific racial thought in the 1850 s, followed by the American Civil War and the Governor Eyre Affair in the 1860s, created a climate in which commentators like Dickens and Sala could take for granted a widespread 
understanding among their readership that white Europeans were an incontrovertibly superior race.

Sala's return to America in 1879, meanwhile, could be seen as little more than an exercise in whitewashing the guilt he felt at backing the South and paving the way for the obligatory lucrative lecture tour (which he duly undertook in 1885). At the outset of his second journey Sala admitted that 'I made up my mind at starting to tread on as few toes as ever I possibly could on this vast continent' $(A R, 1: 126)$. By praising the improvements in the transport system, the cleanliness of the cities, the temperance and diligence of the people, Sala requested that his readers 'let me draw a veil over the melancholy past, and record only the cheerful present' $(A R, 1: 101)$. Determined to paint a positive picture of a forward-thinking nation, he likened the small minority who were prepared to discuss the Civil War to the bores in Britain who recalled all the military engagements of the Waterloo campaign. He even praised the press, noting somewhat disingenuously, 'I admire the newspapers of the United States for the wonderful diversity of their intelligence and for the versatile ingenuity with which the items of that intelligence are strung together.' ( $A R, 2: 122)$ These were sentiments he could trust his readers to agree with. Relations between Britain and the United States had been increasingly respectful after 1865. Indeed the extension of electoral suffrage in England and Wales as a result of the 1867 Reform Act is seen by some as a reflection of the triumph of democracy in the Union. Writing in a later era of Anglo-American strategic relations, George Lillibridge

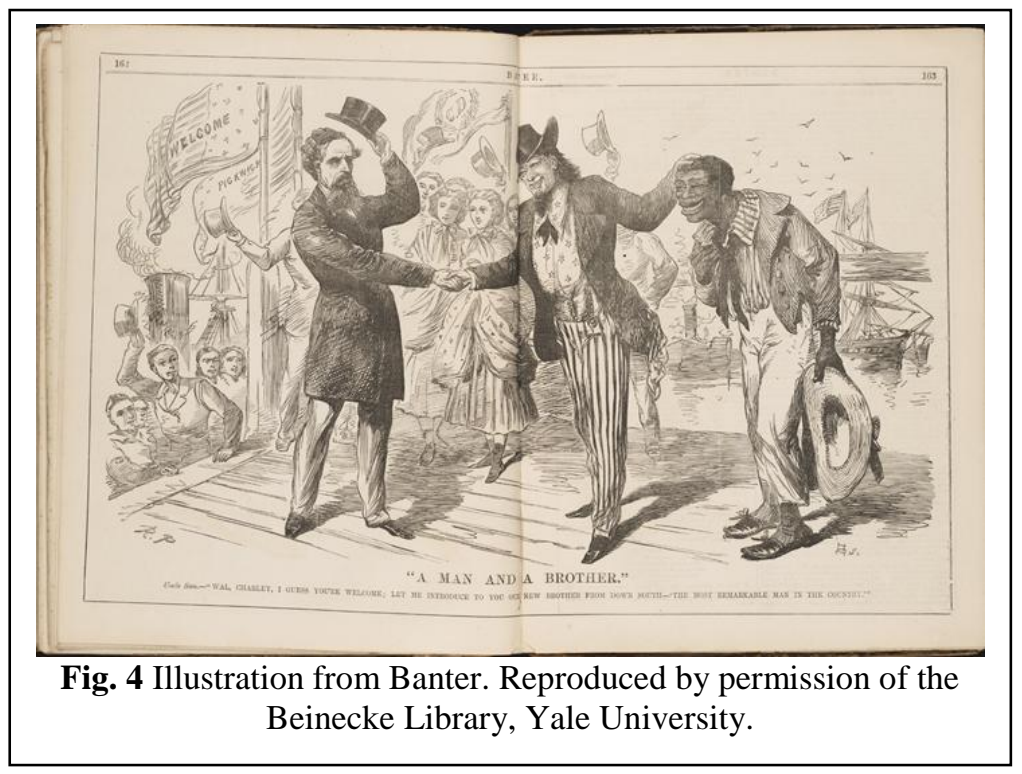
declared in Beacon of Freedom: The Impact of American Democracy upon Great Britain 1830-1870 (1955) that 'though there were many forces and factors leading to the longawaited day in 1867, who will now deny that the role of American destiny was not a humble one in this decisive triumph of the democratic movement in 
England in the nineteenth century?'. ${ }^{3}$ Richard L. Rapson sums up this new mood of respect: 'The Union had remained firm, had triumphed, had even prospered during the course of the bloody conflict. One could still criticise the young nation, but one could no longer consider passing it off with a condescending sneer.' $(B V A, 6)$ The metaphor of youth, so condescendingly used on Sala's first visit, and as an extension of his paternalism regarding slavery, would now be noted as a virtue when describing the urban milieu, 'A youthful American city is more interesting than any monuments of antiquity.' $(A R, 1$ : $282)^{54}$

Sala's return in 1879 was likewise triumphant in tone: he was feted in the South wherever he went, and even in New York he was received without opprobrium, even with some affection. This can be attributed to a number of causes. Sala had shown his own affection for American humour by bringing the attention of the British public to the wit of Artemus Ward and compiling an anthology of American humorists entitled Yankee Drolleries (1866). American journalists and newspapermen had appreciated this. More importantly, the attitude of American commentators towards visiting British critics softened in the aftermath of the Civil War and reconstruction. The time when a Dickens or a Sala could cause mass public indignation through the press had gradually receded. A firmer sense of national identity and prosperity played some part in the altered reception of those Britons who did continue to criticise America, like Sala's nemesis Matthew Arnold. Arnold, who went on the obligatory lecture tour in 1882, was, like other, later British critics of the democracy, treated with disdain and held up as a figure of fun rather than an apostate who could disrupt the democracy. In Culture and Anarchy (1869), Arnold had characterised Americans as being 'just ourselves, with the Barbarians quite left out and the Populace nearly', thus branding all Americans as Philistines. ${ }^{55}$ Rapson notes that Americans' reaction to Arnold's lecture tour differed from the treatment given to Sala and Dickens: 'Arnold was laughed at, abused, satirized, mocked, reduced to insignificance [...] instead of leaving Americans with lasting moral lessons and injured egos, he provided them with an ever-amusing stereotype.' (BVA, 12-13) Americans were no longer so sensitive to Old World criticism and had no intention of 'undergoing another Dickens trauma.' $(B V A, 11)$

By the beginning of the twentieth century the current of influence in AngloAmerican relations - in the press as elsewhere - was perceived to have shifted its direction in a decisive manner. In 1902 W.T. Stead, the pioneer of the New Journalism in Britain, 
'expressed no dismay at the world-wide spread of American ways of doing things, but celebrated it with full gusto.' (BVA, 255) In his book, The Americanization of the World, or the Trend of the Twentieth Century, Stead asked his fellow countrymen to embrace the American way of life and to 'forge powerful British-American ties'. Sala's sensational commentaries on America might not make his part in the early founding of such ties evident but his journalistic practice for the Telegraph was shaped by his encounter with the American press and went on to inform Stead's own development of the New Journalism in the late nineteenth century. Sala's prominent participation in the rapid alteration of British attitudes towards emancipation during the 1860s likewise made him a conduit for the strongly marked fluctuations in racial thinking in the era of the American Civil War and the Jamaican uprising. By the end of his second visit to America in 1879 Sala seems to have opted out of such transatlantic ideological battles and taken refuge in the blandest of platitudes: he stated simply that America was 'a wonderful country and a wonderful people' $(A R, 2: 326)$.

\section{Endnotes}

\footnotetext{
${ }^{1}$ New York Times, 22 July 1853, p. 1.

${ }^{2}$ For more on the Great Exhibition as a colonial project see Tim Barringer, 'The South Kensington Museum and the colonial project' in Colonialism and the Object: Empire, Material Culture and the Museum, ed. by Tim Barringer and Tom Flynn (London: Routledge, 2001), p. 11. For more on the Great Exhibition as a 'nation on display' see Jeffrey A. Auerbach, The Great Exhibiton of 1851: A Nation on Display (New Haven: Yale University Press, 1999).

${ }^{3}$ For more on Sala's work for Dickens and Household Words see Peter Blake, 'George Augustus Sala, Charles Dickens and Household Words' in Dickens Quarterly, 26 (March 2009), 24-40. For more on Sala's bohemianism see his article 'A Tour in Bohemia', Household Words, 8 July 1854.

${ }^{4}$ Adam C. Roberts, Victorian Culture and Society (London: Arnold, 2003), p. 211.

${ }^{5}$ Catherine Hall, White, Male and Middle-Class: Explorations in Feminism and History (Cambridge: Polity Press, 1992), p. 275. Further references to this edition are given after quotations in the text.

${ }^{6}$ Patrick Brantlinger, Rule of Darkness: British Literature and Imperialism 1830-1914 (Ithaca: Cornell, 1988), p. 178.

${ }^{7}$ Tim Barringer, 'Images of otherness and the visual production of difference: race and labour in illustrated texts, 1850-1865', in Shearer West (ed.), The Victorians and Race (Aldershot; Ashgate, 1996), p. 43. Barringer also notes how when grouped together these images of the urban poor actually serve to emphasize their diversity, rather than illustrate Mayhew's 'idea of a unified and nomadic other.' p. 45. Charles
} 
Kingsley would also use the urban 'other' as representing racial difference in his depiction of a sootblackened chimney sweep transformed into a pristine whiteness by fairies in his novel Water-Babies (1863).

${ }^{8}$ Barringer, 'Images of otherness', p. 43.

9 Nancy Stepan, The Idea of Race in Science: Great Britain 1800-1960 (London: Macmillan Press, 1982), p. 44. Further references to this edition are given after quotations in the text.

${ }^{10}$ James Cowles Prichard, Natural History of Man Vol. II (London: Balliere, 1855), p. 714.

13 Thomas Carlyle, Collected Works Vol. VI (London: Chapman and Hall, 1869), p. 202.

${ }^{14}$ Barringer, 'Images of otherness', p. 43.

${ }^{15}$ Cited in Douglas A. Lorimer, Colour, Class and the Victorians (Leicester: Leicester University Press, 1978), p. 94.

${ }^{16}$ Lorimer, p. 123.

${ }^{17}$ Cited in R.J.M. Blackett, Divided Hearts; Britain and the American Civil War (Baton Rouge: Louisiana University State Press, 2001), p. 37.

${ }^{17}$ Blackett, p. 37.

18 Dane Kennedy, The Highly Civilized Man: Richard Burton and the Victorian World (Cambridge, Massachusetts: Harvard University Press, 2005), p. 140.

18 Peter Kolchin, Unfree Labor: American Slavery and Russian Serfdom (Cambridge, Massachusetts: Harvard University Press, 1987), p. 362.

${ }^{19}$ G.A. Sala, A Journey Due North (London: Richard Bentley, 1858), p. 100. Further references to this edition are given after quotations in the text.

${ }^{20}$ Charles Dickens, 'The Noble Savage', Household Words, 11 June 1853, p. 168.

21 Jerome Meckier, Innocents Abroad: Charles Dickens's American Engagements (Kentucky: Kentucky University Press, 1990), pp. 10-11.

${ }^{22}$ Lord Denman, The Chronicle, 'Uncle Tom's Cabin, Bleak House, Slavery and the Slave Trade', p. 35, cited in 'The Secret History of the Dismal Science', Part II Brotherhood, Trade and the Negro Question in <http://www.econlib.org/library/Columns/LevyPeartdismal2.html> [accessed 16/06/09]

${ }^{23}$ Hariet Martineau, 'Freedom or Slavery?', Household Words, 18 September 1852, 537-42.

${ }^{24}$ Eliza Lynn Linton and W.H. Wills, 'Slaves and Their Masters', Household Words, 23 August 1856, p. 137.

${ }^{25}$ William Blanchard Jerrold, 'Food for the Factory', Household Words, 30 November 1850, p. 225.

${ }^{26}$ Daily Telegraph, 24 November 1856, p. 1.

${ }^{27}$ P.D. Edwards, Dickens's Young Men: George Augustus Sala, Edmund Yates and the World of Victorian Journalism (Aldershot: Ashgate, 1997), p. 131.

${ }^{28}$ G.A. Sala, My Diary in America in the Midst of War, 2 Vols (London: Tinsley Brothers, 1865), vol. 1, p. 118. Further references to this edition are given after quotations in the text.

${ }^{29}$ Cited in Edwards, p. 110.

${ }^{30}$ Meckier, p. 76.

${ }^{31}$ Meckier, p. 76.

${ }^{32}$ For more on Sala's relationship with Dickens see Blake.

Peter Blake, George Augustus Sala and the English Middle-Class View of America

19: Interdisciplinary Studies in the Long Nineteenth Century, 9 (2009) www.19.bbk.ac.uk 
${ }^{33}$ Charles Dickens, American Notes for General Circulation, ed. by Patricia Ingham (London: Penguin, 1995), p. xxv.

${ }^{34}$ Edwards, p. 109.

${ }^{35}$ G.A. Sala, The Life and Adventures of George Augustus Sala (London: Cassell \& Co., 1895), p. 311.

${ }^{36}$ Edwards, p. 110.

${ }^{37}$ For liberal support for the Confederacy see, Richard Shannon, Gladstone (London: Hamish Hamilton, 1982). For Tory support see Ephraim Adams, Great Britain and the American Civil War (New York: Russell, 1958). For an excellent overview on both positions, see R.J.M. Blackett, Divided Hearts; Britain and the American Civil War (Baton Rouge: Louisiana University State Press, 2001).

${ }^{38}$ Richard L. Rapson, Britons View America (Seattle: University of Washington Press, 1971), p. 223. Further references to this edition are given after quotations in the text.

${ }^{39}$ Ralph Straus, Sala: The Portrait of an Eminent Victorian (London: Constable \& Co. 1942), p. 173.

${ }^{40}$ Straus, p. 173.

${ }^{41}$ Horace Greeley, New York Tribune, November 1864, p. 93.

${ }^{42}$ For more on Dickens, America and mass media, see Juliet John, 'A body without a head': The Idea of Mass Culture in Dickens's American Notes (1842)', Journal of Victorian Culture, 12 (2007), 173-202.

${ }^{43}$ London Quarterly Review 24:47 (Apr: 1865), 147-71.

${ }^{44}$ Illustrated London News, 11 Feb 1865, p. 142.

${ }^{45}$ Lorimer, p. 179.

${ }^{46}$ Cited in Adam Roberts, Victorian Culture and Society (London: Arnold, 2003), p. 182.

${ }^{47}$ Lorimer, p. 183.

${ }^{48}$ G.A. Sala, 'The Great Circumbendius', Belgravia, 6 (1868), 559-574.

${ }^{49}$ G.A. Sala, America Revisited (London: Vizetelly \& Co., 1882), p. 151. Further references to this edition are given after quotations in the text.

${ }^{50}$ Robert J.C. Young, Colonial Desire (London: Routledge, 2002), p. 102.

${ }^{51}$ Young, p. 152.

${ }^{52}$ Ingham (ed.), p. xxvi.

${ }^{53}$ Cited in Rapson, p. 7. Contemporary approaches to this question have begun to challenge Lillibridge's analysis. See Robert Saunders' paper, 'Let America be the Test': The Idea of American Democracy in British Politics 1832-67', Idea of America in the Nineteenth Century conference, 28 June,2008.

${ }^{54}$ Sala displays the influence of Mark Twain's Innocents Abroad (1869), in which Twain deliberately set Dickens's views of the New World on their head and praised American modernity over Old World antiquity. ${ }^{55}$ Cited in Rapson, p. 13.

I am indebted to the professional research assistance of Professor Robert Cook, Sussex University, in the preparation of this article. 